\title{
Megastigmus transvaalensis (Hymenoptera: Torymidae) on Schinus polygamus (Anacardiaceae): a new native host for this invasive seed-feeding species
}

\author{
Megastigmus transvaalensis (Hymenoptera: Torymidae) en Schinus polygamus \\ (Anacardiaceae): un nuevo huésped nativo para esta especie invasora que se \\ alimenta de semillas
}

\author{
Daniell R.R. Fernandes ${ }^{1 *}$, Claudio Salas ${ }^{2}$, Sergio Rothmann ${ }^{3}$, \\ Rogéria I.R. Lara ${ }^{4}$ Nelson W. Perioto ${ }^{2,4}$
}

\section{RESUMEN}

Este es el primer registro de la interacción entre Megastigmus transvaalensis y semillas de Schinus polygamus, un fruto nativo de América del Sur.

Palabras clave: Chalcidoidea, Chile, Megastigminae, semilla.

\section{ABSTRACT}

This is the first report of the interaction between the seed-feeding M. transvaalensis and S. polygamous, a native fruit from South America.

Key words: Chalcidoidea, Chile, Megastigminae, seed.

Schinus polygamus (Cav.) Cabr. (Sapindales: Anacardiaceae) is native to South America and there are reports of its occurrence in Argentina, Brazil, Peru, Uruguay and Chile (Dias et al., 2013). In Chile it occurs between the regions of Atacama and Los Rios, where is commonly known as "huingán", "borocoi" or "boroco" (Hoffmann, 1998; Erazo et al., 2006).

S. polygamus, often found in sclerophyllous forests, is a perennial shrub about $2.5 \mathrm{~m}$ tall, dioecious, its fruit is a globose drupe about 5 $\mathrm{mm}$ in diameter with color ranging from violet to black (Hoffmann, 1982, 1998). The trunks and branches of this plant are used as firewood by the native population and its fruit makes an alcoholic and non-fermented beverage, which has analgesic, anti-inflammatory and antimicrobial properties (Hoffmann, 1998; Wilhelm, 1999; Erazo et al., 2006). The analgesic and anti-inflammatory properties are associated with the presence of $\beta$-sitosterol, terpenoids, $\beta$-pinene and quercetin, while the antimicrobial activities are associated with essential oils, compounds $\alpha$-pinene, $\alpha$-phellandrene and limonene, identified in the fruit (Erazo et al., 2006).

Many insects attack this plant, such as species of Cecidomyiidae (Diptera), Psylloidea (Hemiptera) and Cecidosidae (Lepidoptera), which induces the formation of galls (Dias et al., 2013). Megastigmus transvaalensis (Hussey) (Hymenoptera: Torymidae, Megastigminae) is a seed-feeding species which was recorded for the first time in Chile by Pujade-Villar \& Caicedo (2010).

1 Instituto Nacional de Pesquisas da Amazônia-INPA, Post-graduate Program in Entomology, Caixa Postal 478, CEP 69011-970, Manaus, Amazonas, Brazil.

2 Universidade Estadual Paulista "Júlio de Mesquita Filho" / Faculdade de Ciências Agrárias e Veterinárias (UNESP/FCAV), Post-graduate Program of Agronomy (Agricultural Entomology), Jaboticabal, São Paulo, Brazil.

3 Servicio Agrícola y Ganadero (SAG), Lo Aguirre, Santiago, Chile.

4 Agência Paulista de Tecnologia dos Agronegócios, APTA Ribeirão Preto, Laboratório de Sistemática e Bioecologia de Parasitoides e Predadores, Ribeirão Preto, São Paulo, Brazil.

* Corresponding autor: daniell.fernandes@ inpa.gov.br 
In this paper we report for the first time the interaction of $M$. transvaalensis with fruits of $S$. polygamus. The specimens of $M$. transvaalensis were obtained from fruits of $S$. polygamus collected in December 2011 in the "Ruta Antakari" sector $\left(30^{\circ} 05^{\prime} \mathrm{S}, 7^{\circ} 43^{\prime} \mathrm{W}, 922 \mathrm{~m}\right.$ above sea level), Elqui Province, Municipality of Vicuña, Coquimbo Region (Plate 1). Plants of $S$. polygamus and S. molle shared the same environment where specimens of M. transvaalensis were collected, which may favor the host succession.

Many species of Megastigmus Dalman can attack native seeds of Anacardiaceae and Pinaceae, and they are treated as quarantine pests in Chile (Resolution No. 792/07 of the Servicio Agrícola y Ganadero de Chile). There are 143 species of Megastigmus in the world (Noyes, 2013), of which about two thirds are phytophagous (Grissell \& Prinsloo, 2001). M. pistaciae Walker, M. rhusi (Hussey), M. thomsensi (Hussey) and M. transvaalensis are associated with Anacardiaceae (Grissell \& Prinsloo, 2001). M. transvaalensis is native to Africa and their larvae feed on Anacardiaceae seeds (Habeck et al., 1989;
Scheffer \& Grissell, 2003) such as Rhus laevigata L. and R. angustifolia L., indigenous trees of South Africa, and S. molle L. and S. terebinthifolius Raddi, from South America (Scheffer \& Grissell, 2003).

Males of M. transvaalensis show great phenotypic variability in body length and coloration, and also a forewing with or without spots, of variable size, close to the stigma (Grissell \& Prinsloo, 2001) (Plate 2).

M. transvaalensis is distributed through several regions of the world because S. terebinthifolius, one of its host plants, is used as an ornamental plant and its fruit is used as a condiment (see Noyes, 2013). Perioto (1997) stated that, in Brazil, seeds of $S$. terebinthifolius attacked by Megastigmus sp., later identified as $M$. transvaalensis, become infertile and Wheeler et al. (2001) in the United States, found that $M$. transvaalensis damaged about $75 \%$ of the seeds of $S$. terebinthifolius analyzed.

The presence of the M. transvaalensis in Chile is cause for concern because this wasp can affect the natural regeneration of South American species of Anacardiaceae, as S. polygamus for example, as reported by Pujade-Villar \& Caicedo (2010).

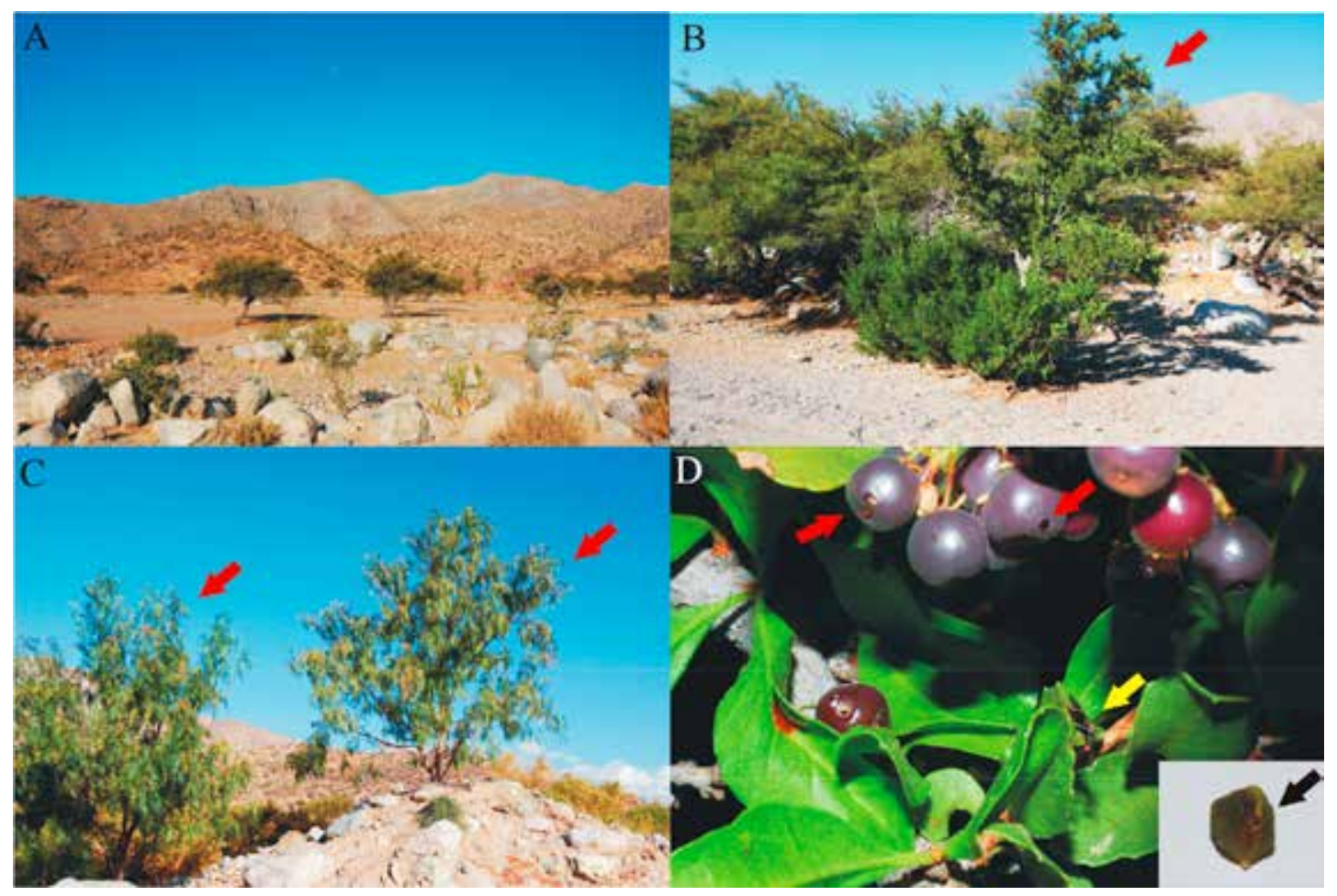

Plate 1. A. Vicuña (Coquimbo), collection site of Schinus polygamus (Cav.) Cabr. and Schimus molle L. (Sapindales: Anacardiaceae). B. S. polygamus (red arrow). C. S. molle (red arrow). D. Exit orifice in fruits of S. polygamus (red arrow), recently emerged male (yellow arrow), and seed with exit orifice (black arrow). 


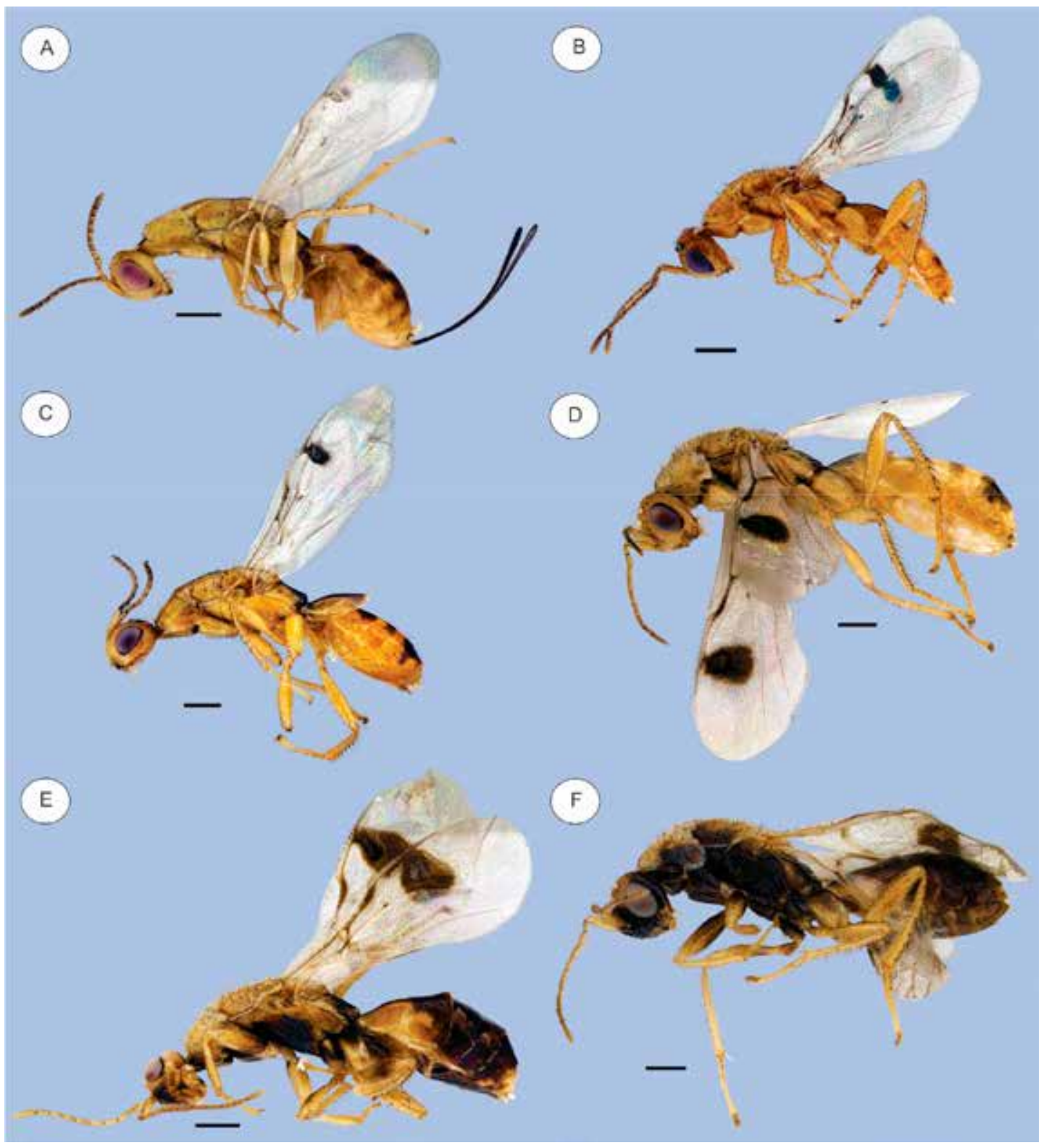

Plate 2. A. Female of Megastigmus tranvaalensis (Hussey) (Torymidae: Megastigminae); B-F. Phenotypic variation in males of M. transvaalensis. Scale bar $=1,0 \mathrm{~mm}$.

\section{Acknowledgments}

We thank MSc Marcelo Ricardo Rosas Cerda, of the Banco de Germoplasma Vicuña, of the Instituto de Investigaciones Agropecuarias (INIA), for the identification of the plants; Instituto Nacional de Ciência e Tecnologia dos
Hymenoptera Parasitoides da Região Sudeste Brasileira (HYMPAR/Sudeste-CNPq/FAPESP/ CAPES) for the financial support; CAPES for the PhD scholarship to the first author. DRRF and CS thank Francisco Sosa, Francisco Díaz and Sérgio de Freitas (in memoriam) for collecting these fruits in Vicuña, Chile. 


\section{Literature Cited}

Dias, G.G.; Moreira, G.R.P.; Ferreira, B.G.; Isaias, R.M.S. 2013. Why do the galls induced by Calophya duvauae Scott on Schinus polygamus (Cav.) Cabrera (Anacardiaceae) change colors? Biochemical Systematics and Ecology, 48: 111-122.

Erazo, S.; Delporte, C.; Negrete R.; García, R.; Zaldívar, M.; Iturra, G.; Caballero, E.; López, J. L.; Backhouse, N.

2006. Constituents and biological activities of Schinus polygamus. Journal of Ethnopharmacology, 107: 395-400.

Grissell, E.E.; Prinsloo, G.L.

2001. Seed-feeding species of Megastigmus (Hymenoptera: Torymidae) associated with Anacardiaceae. Journal of Hymenoptera Research, 10: 271-279.

Habeck, D.H.; Bennett, F.D.; Grissell, E.E.

1989. First record of a phytophagous seed chalcid from Brazilian peppertree in Florida. Florida Entomologist, 72: 378-379.

Hoffmann, A.

1982. Flora silvestre de Chile, Zona Araucana. Santiago, Chile: Fundación Claudio Gay, 258 p.

Hoffmann, A.

1998. Flora silvestre de Chile, Zona Central. Santiago, Chile: Fundación Claudio Gay, 254 p.
Noyes, J.S.

2013. Universal Chalcidoidea Database. World Wide Web electronic publication. http://www.nhm.ac.uk/chalcidoids. Accessed: 19/Feb/2014).

Perioto, N.W.

1997. Primeira ocorrência do gênero Megastigmus Dalman, 1820 (Hymenoptera: Torymidae) e primeiro registro da subfamília Megastigminae para o Brasil. Arquivos do Instituto Biológico, 64: 115-116.

Pujade-Villar, J.; Caicedo, G.

2010. Primera cita de Megastigmus transvaalensis (Hymenoptera, Chalcidoidea, Torymidae) para Colombia. Boletín de la Asociación española de Entomología, 34: 431-433.

Scheffer, S.J.; Grissell, E.E.

2003. Tracing the geographical origin of Megastigmus transvaalensis (Hymenoptera: Torymidae): an African wasp feeding on a South American plant in North America. Molecular Ecology, 12: 415-421.

Wheeler, G.S.; Massey, L.M.; Endries, M.

2001. The Brazilian peppertree drupe feeder Megastigmus transvaalensis (Hymenoptera: Torymidae): Florida distribution and impact. Biological Control, 22: 139-148.

Wilhelm, D.M.

1999. Botánica Indígena de Chile. Santiago, Chile: Editorial Andrés Bello, 140 p. 